\title{
Analisis Metode ICA dan NMFsc untuk Implementasi Sistem Pengenalan Wajah pada Video di Ruangan
}

\author{
Eka Kusumawardhani ${ }^{1}$, Fitri Imansyah ${ }^{2}$, Leonardus Sandy A.P. ${ }^{3}$ \\ 1,2,3 Jurusan Teknik Elektro, Fakultas Teknik, Universitas Tanjungpura \\ Jl. Prof. Dr. H. Hadari Nawawi, Bansir Laut, Kec. Pontianak Tenggara, Kota Pontianak, Kalimantan Barat 78124 \\ lekawardhanidee.untan.ac.id \\ 2fitri.imansyah@ee.untan.ac.id \\ 3leonardusandydee.untan.ac.id
}

\begin{abstract}
Abstrak
Face recognition atau pengenalan wajah merupakan sebuah metode untuk mengidentifikasi atau memverifikasi identitas seseorang melalui wajah. Saat ini, sudah banyak sekali sistem aplikasi dan metode pengenalan wajah yang telah dikembangkan, salah satunya adalah metode ICA dan NMFsc. Penelitian terdahulu pernah menerapkan metode ICA dan NMFsc pada sistem pengenalan wajah dengan masukan berupa citra digital yang memiliki tingat akurasi $96.1 \%$ untuk metode ICA dan 94\% untuk metode NMFsc. Pada penelitian ini, metode ICA dan NMFsc akan kembali diterapkan dalam sistem pengenalan wajah dengan masukan berupa video yang selanjutnya akan dianalisis kinerja metode tersebut terhadap tingkat akurasi dan waktu komputasi sistem. Tingkat akurasi dari kedua metode akan dilihat dari hasil simulasi program pengenalan wajah menggunakan Matlab. Hasil pengujian sistem secara keseluruhan menunjukan bahwa Metode NMFsc memiliki nilai akurasi tertinggi yaitu $92.5 \%$ dengan waktu komputasi 166.8026 s pada kondisi kamera disebelah kiri sedangkan ICA 84.25\% dengan waktu komputasi 51.7315s pada kondisi kamera disebelah kiri.
\end{abstract}

Kata kunci: Pengenalan Wajah, ICA, NMFsc, Citra Digital, Video.

\section{Analysis of ICA and NMFsc Method for the Implementation of Face Recognition Systems on Video in the Room}

\begin{abstract}
Face recognition is a method to identify and verify someone's identity from their face. Many application systems and facial recognition methods have been developed, such as the ICA and NMFsc methods. Previous research has applied the ICA and NMFsc methods to face recognition systems with a digital image as a system input. The result of system accuracy in the previous research is $96.1 \%$ for the ICA method and $94 \%$ for the NMFSc method. In this study, the ICA and NMFsc Methods will be applied again on a face recognition system with video as the input. Then the performance of these methods will be analyzed against the level of accuracy and system computation time. The overall simulation system results show that the NMFsc method has the highest accuracy value of $92.5 \%$, with a computation time of $166.8026 \mathrm{~s}$, while ICA is $84.25 \%$ with a computation time of $51.7315 \mathrm{~s}$.
\end{abstract}

Keywords: Face Recognition, ICA, NMFsc, Digital Image, Video.

\section{Pendahuluan}

Dengan semakin berkembangnya teknologi informasi dan komunikasi, permintaan sebuah sistem dengan tingkat keselamatan dan keamanan yang tinggi secara bertahap juga semakin meningkat. Untuk pertimbangan masalah keaamanan, banyak metode pengenalan wajah yang telah dipelajari dan dikembangkan dalam beberapa tahun belakangan, karena sistem pengenalan wajah banyak digunakan dalam kehidupan kita sehari-hari. Terutama dalam sistem keamanan dan keamanan informasi. Maka dari itu banyak penelitian yang berlomba - lomba untuk meningkatkan akurasi sitem pengenalan wajah dan kecepatan respon sistem pengenalan wajah.
Pengenalan wajah adalah salah satu aplikasi berbasis kecerdasan buatan biometric yang dapat mengidentifikasi wajah sesorang dengan cara menganalisis pola berdasarkan tekstur dan bentuk wajah orang tersebut. Sistem pengenalan wajah adalah teknologi yang mampu mengidentifikasi seseorang dari sumber citra digital ataupun video [1],[19]. Pada dasarnya teknik pengenalan wajah dapat diklasifikasikan dalam dua kategori yaitu metode feature based dan metode holistic [2],[3],[18]. Dalam metode feature based, beberapa fitur geometris seperti posisi dan lebar mata, hidung, dan ketebalan alis diekstraksi untuk merepresentasikan wajah. Sebaliknya, dalam metode holistic, seluruh wajah diambil sebagai masukan untuk melakukan pengenalan wajah. Penilitian 
ini akan membandingkan akurasi dan waktu komputasi dari dua metode pengenalan wajah holistic.

Metode-metode pengenalan wajah sudah banyak yang diterapkan pada citra dari berbagai penelitian, dimana setiap metode memiliki ciri-ciri, parameter dan tingkat akurasi yang berbeda-beda pada keluaran suatu program. Salah satunya adalah metode Independent Component Analysis (ICA) dan Non-negative Factorization Matrix with sparseness constraints (NMFsc) [15]. Pada penelitian [4] kedua metode tersebut diterapkan pada sistem pengenalan wajah dengan masukan berupa citra digital dan sudah memiliki akurasi yang cukup besar. Metode ICA memililiki tingkat akurasi sebesar 94\%, sedangkan metode NMFsc memiliki tingkat akurasi terbesar yaitu $96.1 \%$. Namun, penelitian tersebut masih memiliki beberapa kekurangan salah satunya ada waktu komputasi sistem yang masih tinggi.

Dalam penelitian ini akan dibuat suatu sistem pengenalan wajah dengan masukan berupa rekaman video di ruangan menggunakan metode Independent Component Analysis (ICA) dan Non-negative Matrix Factorization with Sparseness Constrait (NMFsc). Untuk mengetahui kinerja metode ICA dan NMFsc pada sistem tersebut, beberapa skenario pengujian akan dilakukan. Analisis kinerja metode akan dilihat dari tingkat akurasi dan waktu komputasi dari sistem tersebut dan parameter-parameter yang mempengaruhi tingkat akurasi dan waktu komputasi sistem.

\section{MEtodologi}

\section{A. Metode Independent Component Analysis (ICA)}

Independent Component Analysis (ICA) merupakan metode pengenalan wajah yang didasarkan pada statistika orde banyak [5]. Penerapan ICA digunakan untuk mencari komponen-komponen independen dari wajah sehingga suatu wajah tersebut dapat dinyatakan sebagai kombinasi linear dari komponen-komponen independen yang telah ditemukan. Pada awal algoritma ICA terdapat dua buah tahapan yaitu preprocessing dan dekolerasi [6]. Tahapan ini ditujukan untuk meningkatkan kemampuan ICA dalam mengestimasi matriks dekomposisi sehingga kualitas keluaran yang akan dihasilkan algoritma ICA dapat ditingkatkan.

Secara garis besar (dapat dilihat pada gambar 1) tujuan dari tahapan tersebut adalah untuk meningkatkan ketepatan algoritma ICA didalam melakukan estimasi sumber sinyal dengan cara menurunkat tingkat kompleksitas data dan membuang data yang tidak diperlukan. Pada penelitian kali ini akan jenis metode ICA yang akan kami gunakan adalah fastICA, karena fastICA dapat membedakan elemen atau komponen campuran matriks secara independen [7].

Pada metode fastICA (dapat dilihat pada gambar 2), yang pertama kali dilakukan adalah mengestimasi sumber sinyal dari campuran sinyal. Berikut bentuk persamaan matematisnya :

$$
x=A s
$$

Tujuan utama dari estimasi tersebut adalah untuk mengestimasi nilai dari A sehingga kita akan mengetahui nilai dari $\mathrm{x}$ yang merupakan sinyal campuran. Berdasarkan persamaan (1), dengan mengetahui nilai dari A, maka kita dapat menghitung sumber sinyal s :

$$
s=A^{-1} \chi
$$
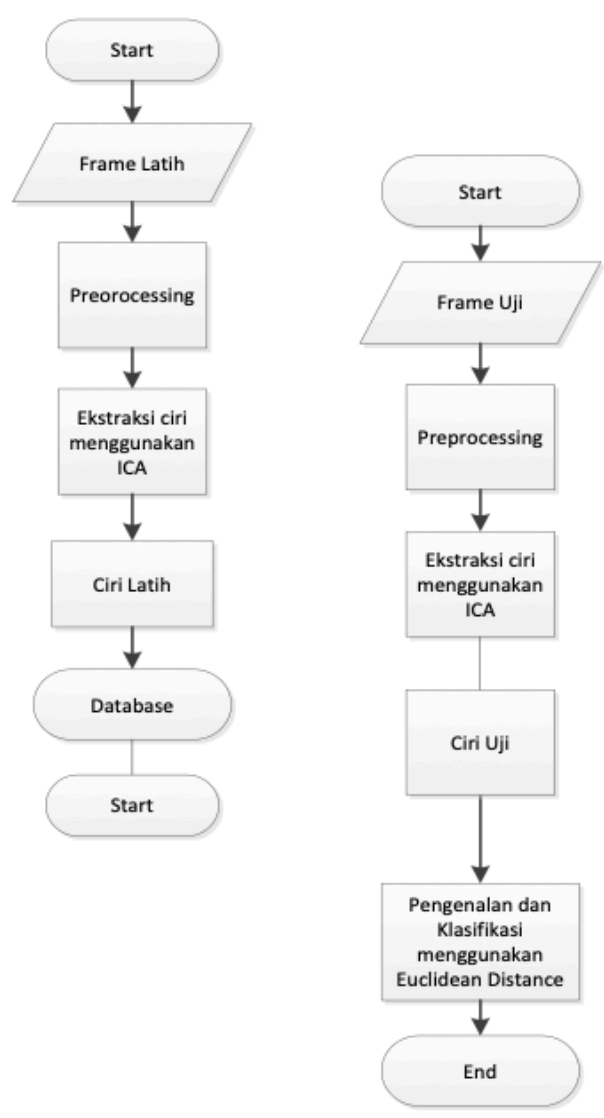

Gambar 1. Diagram Alir Proses Latih dan Proses Uji Metode ICA

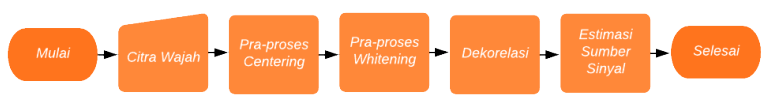

Gambar 2. Flowchart fastICA

Tahapan selanjutnya adalah preprocessing yang meliputi proses centering dan whitening [8]. Proses centering memusatkan data dengan cara mengurangi setiap elemen $\mathrm{x}$ dengan mean-nya sehingga $\mathrm{x}$ memiliki nilai mean nol. Kemudian proses whitening dilakukan untuk mendapatkan nilai $\mathrm{x}$ dengan unit-variance [9]. Proses whitening menggunakan dekomposisi SVD sebagai berikut :

$$
z=\left(\bigcup \Sigma^{-1}\right)^{T} x
$$


Dimana $\bigcup$ adalah unitary matriks dengan kolom berupa eigenvector dari $\mathrm{x}$, dan matriks $\Sigma$ sebagai diagonal matriks dari $x$. Tahapan fastICA seanjutnya adalah proses dekorelasi untuk mengestimasi nilai matriks w, dimana nilai matriks w yang konvergen dapat digunakan sebagai matriks A pada persamaan (2). Dari hasil proses whitening, $\mathrm{z}$ kemudian didekorelasi dengan skema deflation, berikut adalah skema deflation [5].

1. Penginisialisasian vektor bobot w (biasanya dibangkitkan secara acak).

2. $\mathrm{w}^{+}=\mathrm{E}\{\mathrm{xg}(\mathrm{wTx})\}-\mathrm{E}\left\{\mathrm{g}^{\prime}(\mathrm{wTx})\right\} \mathrm{w}$

3. $\mathrm{w}=\mathrm{w}+/\|\mathrm{w}+\|$

4. Apabila belum konvergen, kembali ke-2.

Tahapan terakhir dari fastICA adalah mengestimasi sumber sinyal yang independen menggunakan persamaan :

$$
s=W\left(\bigcup \Sigma^{-1}\right)^{T} x
$$

\section{B. Metode Non-Negative Matrix Factorization with Sparseness Constraints (NMFsc)}

Metode NMFsc (Non Negative Matrix Factorization with Sparseness Constraints) merupakan metode yang telah dikembangkan setelah metode NMF (Non Negative Matrix Factorization), karena NMF masih memiliki waktu komputasi yang cukup lama [10],[17]. Metode NMF membutuhkan waktu komputasi yang lebih lama untuk mencapai konvergensi. Untuk mengatasi ini, seorang peneliti bernama Hoyer [11],[14] mengusulkan metode NMFsc yang menunjukkan bahwa metode NMFsc dapat mencapai konvergensi yang lebih cepat daripada NMF. Pada intinya metode ini mencari level sparse pada citra wajah yang nantinya akan dijadikan sebagai ciri dari wajah manusia. Sebenarnya cara kerja NMFsc ini masih sama dengan metode NMF[16], dimana ada masukan matriks $\mathrm{V}$ yang berukuran $\mathrm{m} \times \mathrm{n}$, yang kemudian akan direduksi terlebih dahulu. Persamaan (3) menunjukkan rumus dari NMFsc yang pada dasarnya sama dengan rumus NMF ataupun LNMF [12], yaitu :

$$
V \approx W
$$

Untuk memenuhi persamaan (5), maka harus dicari dulu matriks $\mathrm{W}$ dan $\mathrm{H}$, dimana ukuran matriks $\mathrm{W}$ ( $\mathrm{m} \times \mathrm{r}$ ) dan $\mathrm{H}$ ( $\mathrm{r} \times \mathrm{n}$ ). Nilai $\mathrm{r}$ dapat kita tentukan secara random, namun dalam menentukan nilai $r$ harus tepat, karena nilai $r$ juga akan mempengaruhi proses ekstraksi ciri. Selanjutnya nilai $S_{u}$ dan $S_{h}$ juga perlu di inisialisasi, dimana nilai tersebut merupakan tingkat sparseness dari sebuah citra, rentang dari nilai $S_{u}$ dan $S_{h}$ adalah 0-1. Selanutnya menentukan ukuran penyebaran sparseness yang didasarkan pada hubungan variable norm $L_{1}$ dan $L_{2}$, dengan menggunakan nilai $S_{u}$ dan $S_{h}$ yang telah ditentukan. Dengan menggunakan persamaan berikut, batasan penyebaran sparseness dapat ditentukan :

$$
\operatorname{sparseness}(x)=\left(\sqrt{n}-\left(\sum\left|x_{i}\right|\right) / \sqrt{\sum x_{i}^{2}}\right) / \sqrt{n}-1
$$

Dimana $n$ merupakan nilai dimensi dari x. Fungsi diatas berguna untuk menyatukan jika dan hanya jika $\mathrm{x}$ berisi hanya komponen tunggal non-negative, dan mengambil nilai nol jika dan hanya jika semua komponen yang sama.

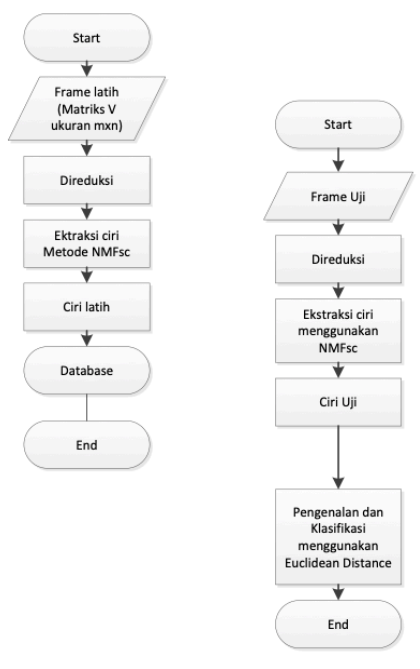

Gambar 3. Diagram Alir Proses Latih dan Proses Uji Metode NMFsc

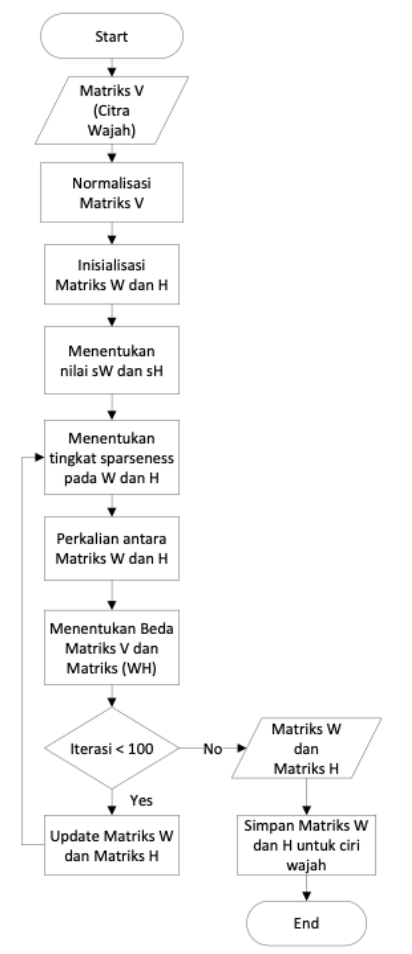

Gambar 4. Diagram Alir Metode NMFsc

Untuk lebih jelasnya, berikut adalah algoritma dari metode NMFsc [20]:

1. Menginisialisasi matriks $\mathrm{W}$ dan $\mathrm{H}$ secara random

2. Matriks $\mathrm{W}$ dan $\mathrm{H}$ tersebut dicari tingkat sparseness nya

3. Di cari beda antara matriks $\mathrm{V}$ dengan perkalian matriks WH dengan menggunakan persamaan dibawah ini :

$$
D(V \| W H)=\sum|(V-W H)|^{2}
$$


4. Update matriks $\mathrm{W}$ dan $\mathrm{H}$, Jika yang digunakan adalah $S_{u}$ maka digunakan persamaan (8) untuk memperbarui nilai matriks $\mathrm{W}$, Jika digunakan $S_{h}$ maka digunakan persamaan (9) untuk memperbarui nilai matriks $\mathrm{H}$ :

$$
\begin{aligned}
& W=W-\mu_{H}(W H-V) H^{T} \\
& H=H-\mu_{W}(W H-V) W^{T}
\end{aligned}
$$

\section{Perancangan Sistem}

Perancangan sistem terdiri dari dua mode yaitu mode penargetan dan mode pengujian. Berikut ini adalah diagram alir secara keseluruhan yang menerangkan cara kerja sistema:

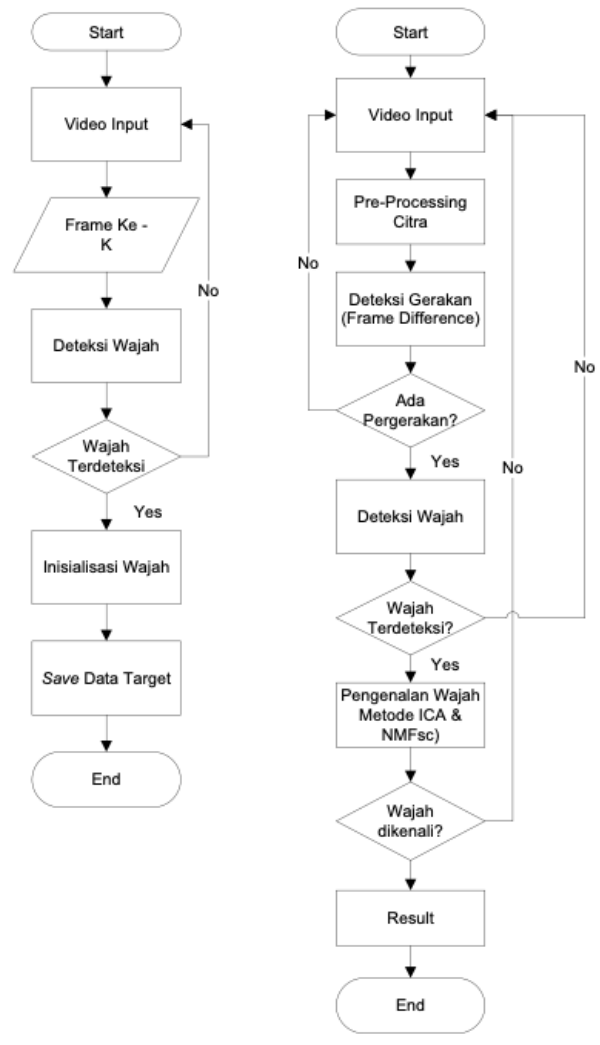

Gambar 5. Diagram Sistem Pengenalan Wajah Secara Keseuruhan

Pada mode penargetan dilakukan inisialisasi wajah per3 frame yang kemudian hasilnya akan dimasukkan ke database sistem dan dibandingkan dengan mode pengujian sistem. Berikut adalah alur dari mode penargetan sistem:

1. Input video yang digunakan sebagai video uji

2. Video kemudian di-tracing per-3 frame

3. Jika pada frame tersebut terdapat wajah yang terdeteksi, maka akan dilakukan inisialisasi wajah, proses ini dilakukan hingga frame terakhir pada video

4. Data mode penargetan kemudian disimpan

Pada Gambar 6 dan Gambar 7 merupakan proses mode penargetan dalam suatu video pada frame ke-0 dan frame ke-223.

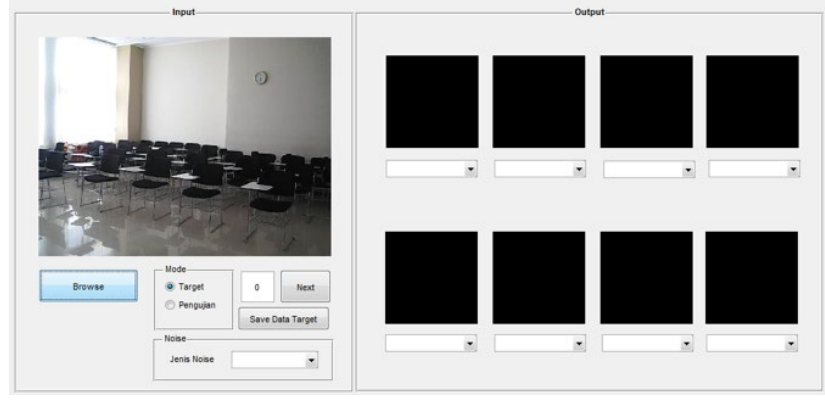

Gambar 6. Mode Penargetan pada frame ke-0

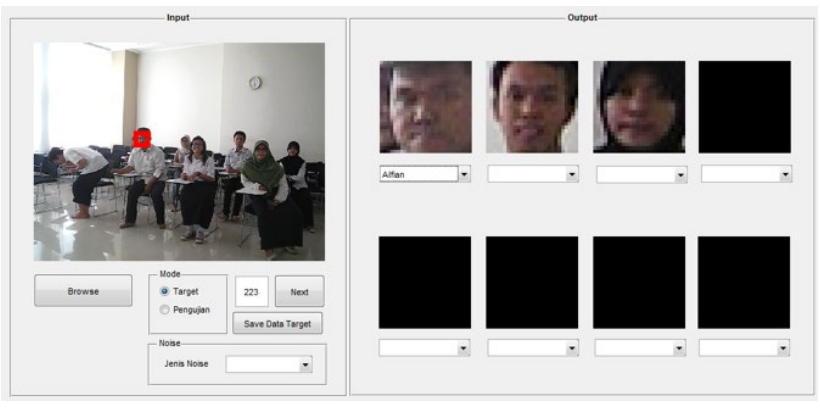

Gambar 7. Mode Penargetan pada frame ke-223

Mode pengujian sistem merupakan mode untuk melakukan pengujian akurasi sistem, dimana masukan dari mode pengujian akan dibandingkan dengan database wajah yang sudah diperoleh dari mode penargetan.

Pada mode pengujian terdapat blok masukan video dimana video yang digunakan merupakan hasil rekaman dari video yang disimpan dalam bentuk file jpeg dengan resolusi $640 \times 480$ piksel berjenis true color. Setelah file video diambil, lalu akan dilakukan proses ekstraksi frame untuk mendapatkan frame dalam video yang disusun dalam bentuk citra digital yang berurutan. Dengan ekstraksi ciri pengolahan video dapat dilakukan dengan pendekatan pengolahan citra digital. Keluaran dari subsistem adalah frame RGB.

Kemudian frame RGB tersebut akan melalui proses konversi dari citra digital berjenis RGB yang berurut tersebut kedalam bentuk citra digital berjenis grayscale. Proses konversi dilakukan karena pengolahan pada citra grayscale lebih sederhana dan efisien dalam komputasi dibandingkan dengan pengolahan citra RGB.

Selanjutnya frame grayscale dari proses konversi akan diolah sesuai dengan metode deteksi gerakan yang digunakan yaitu frame difference. Pada metode ini perbandingan dilakukan per-frame antara frame $\mathrm{ke}-\mathrm{k}$ dengan frame ke - (k-1). Perhitungan yang dilakukan seperti persamaan berikut :

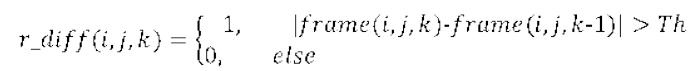

Hasil absolut selisih frame ke - k dengan frame ke - (k1) akan dibandingkan dengan suatu nilai threshold (Th). Jika hasil absolut frame selisih frame lebih besar dari nilai threshold maka disebut dengan objek bergerak atau latar depan sedangkan jika hasil tersebut lebih kecil dari nilai 
threshold maka akan dianggap sebagai latar belakang. Nilai threshold digunakan untuk memberi batasan terhadap nilai selisih frame agar latar depan yang didapat hanya mewakili objek yang dimaksud, dalam hal ini manusia. Nilai threshold yang didapat secara manual dengan metode-trial-and-error. Threshold yang digunakan pada sistema ini sebesar 0.05. Keluaran dari blok ini adalah latar depan yang akan diolah lebih lanjut dalam proses deteksi wajah dan akan dilanjutkan dengan proses pengenalan wajah menggunakan metode ICA dan NMFsc yang telah dijelaskan sebelumnya.

\section{HASIL DAN PEMBAHASAN}

Untuk mengetahui keakuratan serta keefektifan sistem yang telah dirancang dan dibuat, maka sistem akan diuji dan disimulasikan dalam beberapa skenario pengujian. Pada bagian ini akan dibahas mengenai beberapa skenario pengujian yang digunakan untuk menguji tingkat akurasi dan waktu komputasi dari sistem yang telah dibuat beserta hasil-hasil pengujiannya. Selanjutnya akan dianalisa berdasarkan hasil yang telah didapatkan. Berikut adalah scenario pengujian sistem :

1. Pada skenario pertama akan dilihat bagaimana pengaruh nilai sparseness yang diberikan pada matriks $\mathrm{W}$ dan $\mathrm{H}$ metode NMFsc terhadap tingkat akurasi dan waktu komputasi sistem. Pengujian akan dilakukan sebanyak lima video untuk masingmasing nilai sparseness dan menghitung tingkat akurasi dan waktu komputasi sitem.

2. Pada skenario kedua akan dilihat bagaimana pengaruh nilai threshold frame difference yang diberikan terhadap tingkat akurasi sistem. Pengujian akan dilakukan sebanyak 10 video dan menghitung tingkat akurasi dan komputasi sistem. Dari sepuluh percobaan video tersebut akan dihitung nilai akurasi rata-rata dari keluaran system.

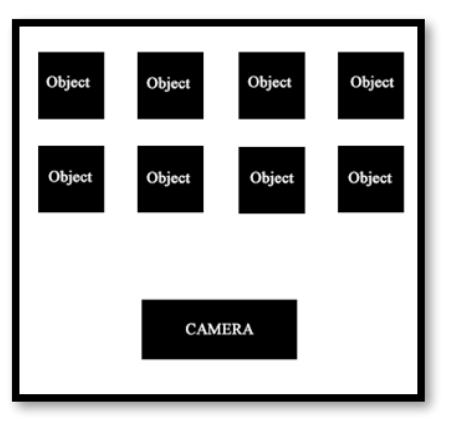

Gambar 8. Posisi Objek Terhadap Kamera pada Skenario Pengujian 1,2 , dan 3

3. Pada skenario ketiga akan dilihat bagaimana pengaruh intensitas cahaya terhadap tingkat akurasi sistem. Video uji akan direkam ketika lampu dalam keadaan menyala dan mati kemudian letak pemasangan kamera berada ditengah. Pengujian akan dilakukan sebanyak sepuluh video untuk masing-masing waktu pengujian dan menghitung tingkat akurasi sistem. Dari seluruh percobaan di masing-masing kondisi tersebut dihitung nilai akurasi rata-rata dari keluaran sistem.
4. Pada skenario keempat akan dilakukan pengambilan video letak pemasangan kamera disebelah kanan, kiri, dan tengah ruangan. Proses ini dilakukan untuk menganalisa pengaruh perpindahan posisi kamera terhadap tingkat akurasi sistem. Pengujian akan dilakukan sebanyak sepuluh video. Dari sepuluh percobaan video tersebut akan dihitung nilai akurasi rata-rata dari keluaran sistem

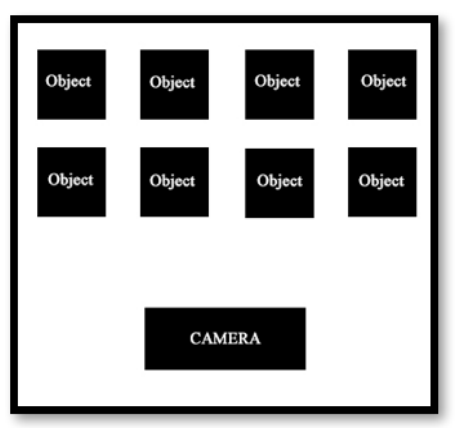

Gambar 9. Posisi Objek Terhadap Kamera pada Skenario Pengujian 4

Dalam pengujian sistem dengan skenario pengujian, parameter-parameter yang akan diperhitungkan adalah tingkat akurasi dan waktu komputasi. Untuk menentukan tingkat akurasi pada masing-masing video uji digunakan rumus berikut ini :

$$
\text { Tingkat Akurasi }=\frac{\text { Jumlah Wajah dikenali dan benar }}{\text { Jumlah Wajah objek di Video }} \times 100 \%
$$

Sedangkan untuk menentukan tingkat akurasi pada masing-masing skenario dihitung dengan merata-ratakan nilai akurasi pada seluruh video uji, dengan menggunakan rumus berikut :

$$
\text { Tingkat Akurast }=\frac{\text { Video uji } 1+\text { Video uji } 2+\cdots+\text { Video Ujin }}{\text { Jumlah Video Uji }} \times 100 \%
$$

Waktu komputasi merupakan waktu yang dibutuhkan sistem untuk melakukan suatu proses. Secara rumus, waktu komputas dapat dihitung dengan cara berikut :

$$
\text { Waktu Komputasi }=T p p+T f d+T d w+T \gamma
$$

Dimana Tpp adalah waktu pre-processing, Tfd adalah waktu frame difference, Tdw adalah waktu deteksi wajah, Tp adalah waktu pengenalan.

Skenario pertama dilakukan untuk melihat pengaruh sparseness yang diberikan pada matriks $\mathrm{W}$ dan $\mathrm{H}$ ketika menggunakan metode NMFsc terhadap tingkat akurasi sistem dan waktu komputasinya. Pengujian dilakukan sebanyak lima data video dan diambil rata-ratanya untuk menghitung akurasi dan waktu komputasi sistem. Berikut adalah hasil pengujian yang telah dilakukan pada skenario pertama. 
TABEL I

PENGARUH Nilai SPARSENESS TERHADAP TINGKAT AKURASI DAN WAKTU KOMPUTASI SISTEM.
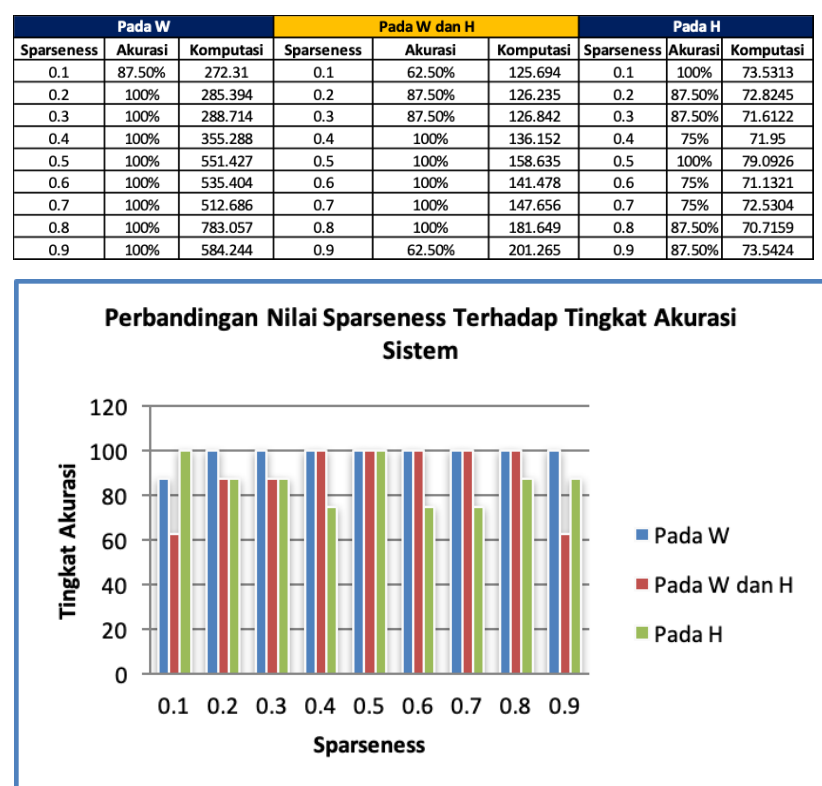

Gambar 10. Grafik Tingkat Akurasi pada Skenario Pertama

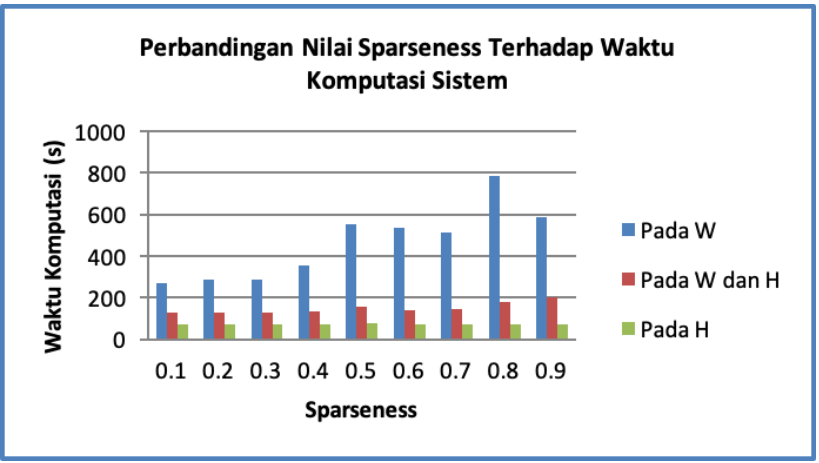

Gambar 11. Grafik Waktu Komputasi Sistem Skenario Pertama

Dari gambar 10 dan gambar 11 terlihat bahwa ketika nilai sparseness diberikan pada matriks $\mathrm{W}$ menghasilkan tingkat akurasi yang lebih baik dan stabil akan tetapi memiliki waktu komputasi yang lebih lama. Ketika nilai sparseness diberikan kepada kedua matriks $\mathrm{W}$ dan $\mathrm{H}$ tingkat akurasi mencapai nilai $100 \%$ pada $0.4,0.5,0.6,0.7$, dan 0.8 dengan waktu komputasi yang lebih singkat dibandingkan dengan nilai sparseness yang diberikan pada matriks W saja. Ketika nilai sparsenes diberikan kepada matriks $\mathrm{H}$ saja tingkat akurasi akurasi mencapai nilai $100 \%$ pada nilai sparseness 0.1 dan 0.5 dengan waktu komputasi yang lebih singkat dari kedua percobaan sebelumnya.

Skenario kedua dilakukan untuk melihat pengaruh threshold frame difference yang diberikan terhadap tingkat akurasi sistem dan waktu komputasi. Nilai perbedaan threshold yang digunakan adalah 0.01, 0.05, 0.5 , dan 1 . Setiap video dilakukan percobaan sebanyak 5 kali sebanyak 10 data video dan diambil rata-ratanya untuk menghitung akurasi dan waktu komputasi sistem.
Berikut adalah tabel pengujian metode ICA dan NMFsc yang akan dilakukan pada skenario kedua.

TABEL II

Pengujian SKenario Kedua
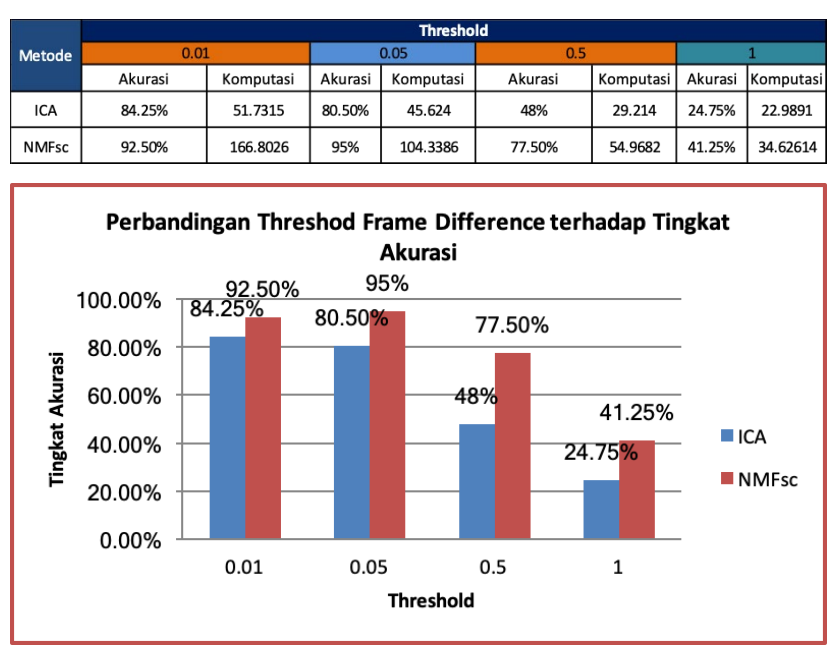

Gambar 12. Grafik Tingkat Akurasi pada Skenario Kedua

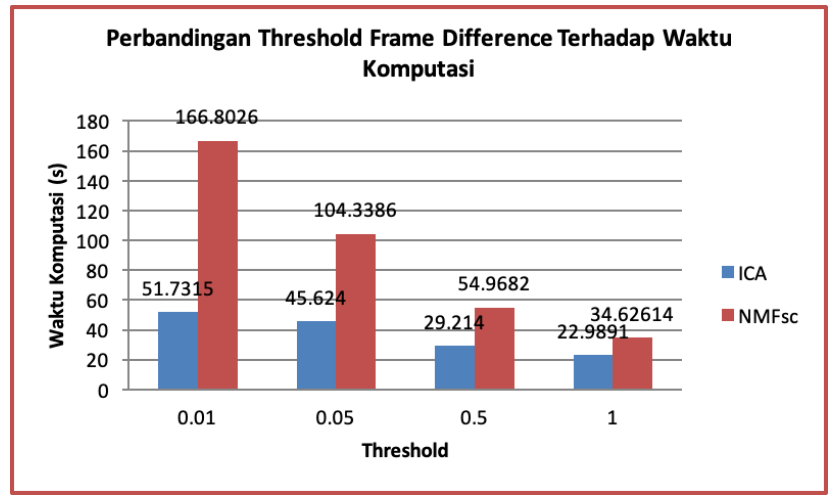

Gambar 13. Grafik Waktu Komputasi Sistem Skenario Kedua

Dari gambar 12 dan gambar 13 dapat disimpulkan bahwa nilai threshold yang paling optimum berada di nilai 0.01 dengan tingkat akurasi $84.25 \%$, waktu komputasi $51.7315 \mathrm{~s}$ untuk metode ICA dan nilai threshold yang paling optimum untuk metode NMFsc adalah 0.05 dengan tingkat akurasi $95 \%$ waktu komputasi 104.3386 s. Tingkat akurasi paling rendah berada pada nilai threshold 1 dengan tingkat akurasi $24.75 \%$ waktu komputasi $22.9891 \mathrm{~s}$ untuk metode ICA dan $41.25 \%$ dengan waktu komputasi $34.62614 \mathrm{~s}$ untuk metode NMFsc. Nilai threshold 0.01 dan 0.05 masih diangap cukup baik karena rata-rata tingkat akurasi yang masih cukup tinggi, yaitu di atas 80 persen untuk kedua metode.

Skenario ketiga dilakukan untuk melihat pengaruh intensitas cahaya pada lampu ketika dalam keadaan mati dan menyala terhadap tingkat akurasi sistem dan waktu komputasi. Setiap video dilakukan percobaan sebanyak 5 kali sebanyak 10 data video dan diambil rata-ratanya untuk menghitung akurasi dan waktu komputasi sistem. Berikut adalah tabel pengujian metode ICA dan NMFsc yang akan dilakukan pada skenario ketiga. 
TABEL III

PENGUJIAN SKENARIO KETIGA

\begin{tabular}{|c|c|c|c|c|c|}
\hline \multirow{2}{*}{ No } & \multirow{2}{*}{ Nama Video } & \multicolumn{2}{|c|}{ ICA } & \multicolumn{2}{c|}{ NMFsc } \\
\cline { 3 - 6 } & $\begin{array}{c}\text { Akurasi Rata- } \\
\text { rata }\end{array}$ & $\begin{array}{c}\text { Waktu } \\
\text { Komputasi }\end{array}$ & $\begin{array}{c}\text { Akurasi Rata- } \\
\text { Rata }\end{array}$ & $\begin{array}{c}\text { Waktu } \\
\text { Komputasi }\end{array}$ \\
\hline 1 & Lampu Nyala & $50.25 \%$ & 39.378 & $70.00 \%$ & 82.14 \\
\hline 2 & Lampu Mati & $59.50 \%$ & 41.71 & $75.00 \%$ & 71.87062 \\
\hline
\end{tabular}

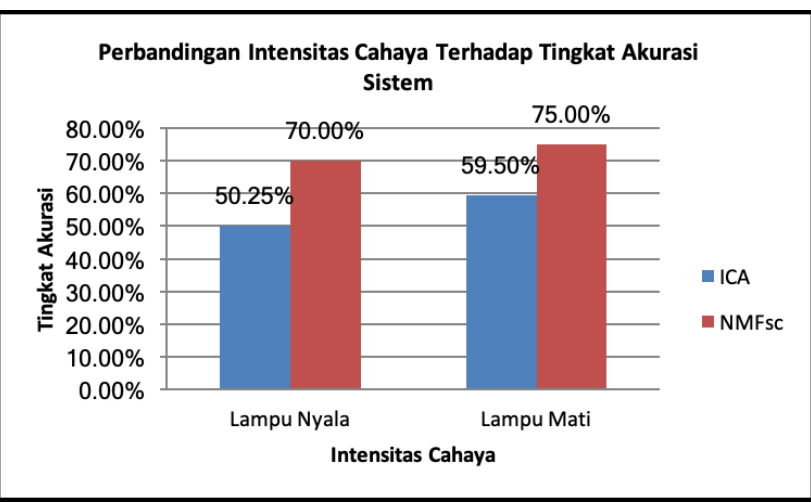

Gambar 14. Grafik Tingkat Akurasi pada Skenario Ketiga

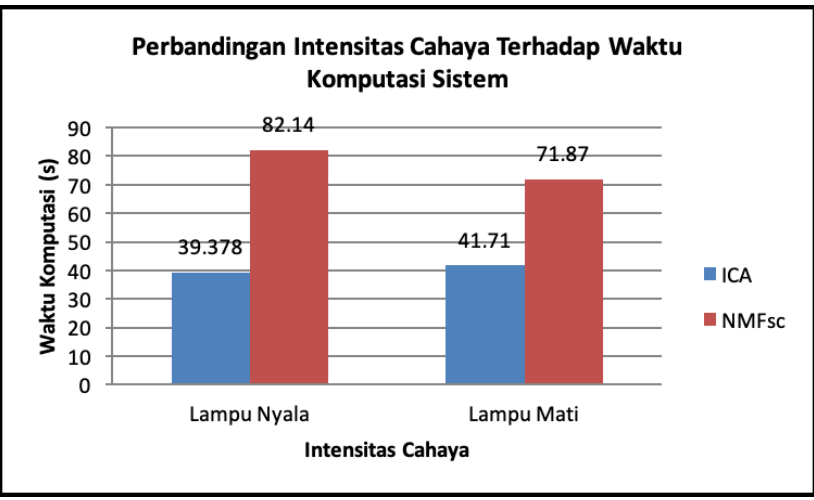

Gambar 15. Grafik Waktu Komputasi Sistem Skenario Ketiga

Dari gambar 14 dan gambar 15 atas terlihat bahwa intensitas cahaya di dalam ruangan tidak begitu mempengaruhi kinerja sistem karena intensitas cahayanya yang relatif mirip. Tetapi pengujian pada keadaan lampu mati memiliki tingkat akurasi yang lebih tinggi pada kedua metode yaitu $59.50 \%$ dengan waktu komputasi 41.71s untuk metode ICA dan $75 \%$ dengan waktu komputasi $71.87 \mathrm{~s}$ untuk metode NMFsc. Oleh karena itu dapat disimpulkan bahwa intensitas cahaya pada keadaan lampu mati adalah kondisi yang paling optimum.

Skenario keempat dilakukan untuk melihat pengaruh posisi kamera video terhadap tingkat akurasi sistem dan waktu komputasi. Posisi kamera terletak disebelah kanan, tengah, dan kiri ruangan. Setiap video dilakukan percobaan sebanyak 5 kali dari 10 video dan diambil rataratanya untuk menghitung akurasi dan waktu komputasi sistem. Berikut adalah tabel pengujian metode ICA dan NMFsc yang akan dilakukan pada skenario keempat.
TABEL IV

PENGUJIAN SKENARIO KEEMPAT

\begin{tabular}{|c|c|c|c|c|c|}
\hline \multirow{2}{*}{ No } & \multirow{2}{*}{ Nama Video } & \multicolumn{2}{|c|}{ ICA } & \multicolumn{2}{c|}{ NMFsc } \\
\cline { 3 - 6 } & & Akurasi Rata-rata & Waktu Komputasi & Akurasi Rata-Rata & Waktu Komputasi \\
\hline 1 & Kanan & $21.00 \%$ & 34.1371 & $33.57 \%$ & 45.15045 \\
\hline 2 & Tengah & $50.25 \%$ & 39.378 & $75.00 \%$ & 71.87062 \\
\hline 3 & Kiri & $84.25 \%$ & 51.7315 & $92.50 \%$ & 166.8026 \\
\hline
\end{tabular}

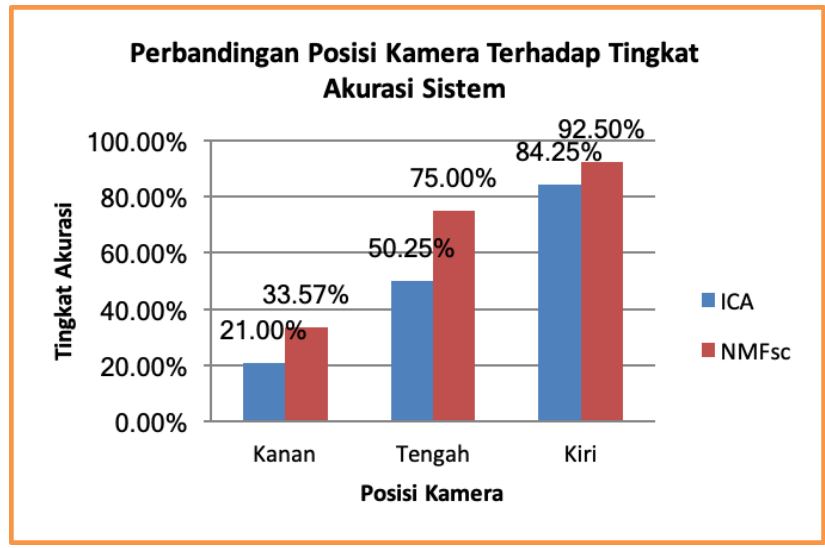

Gambar 16. Grafik Tingkat Akurasi pada Skenario Keempat

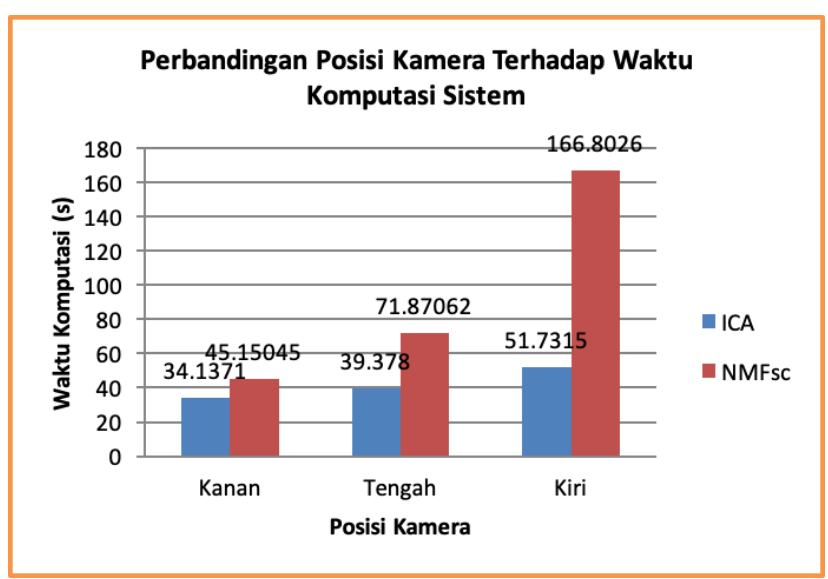

Gambar 17. Grafik Waktu Komputasi Sistem Skenario Keempat

Dari gambar 16 dan gambar 17 terlihat bahwa pengaruh posisi kamera mempengaruhi kinerja sistem pada metode ICA dan NMFsc. Pengujian pada posisi kamera disebelah kiri memiliki tingkat akurasi yang lebih tinggi pada dikedua metode yaitu mencapai angka $84.25 \%$ dengan waktu komputasi $51.7315 \mathrm{~s}$ untuk metode ICA dan $92.5 \%$ dengan waktu komputasi 166.8026s untuk metode NMFsc. Posisi kamera disebelah kanan memiliki tingkat akurasi yang paling rendah disebabkan oleh pengaruh cahaya dari jendela yang menyebabkan backlight sehingga objek susah untuk dideteksi dan dikenali. Oleh karena itu dapat disimpulkan bahwa posisi kamera disebelah kiri adalah kondisi yang paling optimum.

\section{KESIMPULAN}

Dari hasil pengujian dan analisis simulasi dalam penelitian ini dapat disimpulkan secara keseluruhan bahwa kedua metode mencapai nilai akurasi tertinggi ketika posisi kamera disebelah kiri. Metode NMFsc memiliki nilai akurasi tertinggi yaitu $92.5 \%$ dengan waktu 
komputasi 166.8026s sedangkan ICA 84.25\% dengan waktu komputasi 51.7315s. Pengaruh nilai sparseness pada metode NMFsc tidak memberikan perbedaan yang signifikan pada tingkat akurasi dan waktu komputasi sistem, sama halnya dengan pengaruh intensitas cahaya lampu pada pengujian sistem. Karena data video pengujian diambil pada kondisi siang hari.

\section{DAFTAR PUSTAKA}

[1] L. Fang, M. Fu, S. Sun and Q. Ran, "Overview of Face Recognition Methods," in International Conference On Signal And Information Processing, Networking And Computers, Springer, 2018, pp. 22-31.

[2] S. Karamizadeh, S. M. Abdullah and M. Zamani, "An overview of holistic face recognition,” IJRCCT, vol. 2, no. 9, pp. 738-741, 2013.

[3] Tseng and Stewart, "Comparison of holistic and feature based approaches to face recognition," Masters of Applied Science in Information Technology thesis, School of Computer Science and Information Technology, Faculty of Applied Science, Royal Melbourne Institute of Technology University, Melbourne, Victoria, Australia , 2003.

[4] I. Ciocoiu and H. Costin, "Localized versus locality-preserving subspace projections for face recognition," EURASIP Journal on Image and Video Processing, pp. 1-8, 2007.

[5] T. F. Chan and J. Shen, Image processing and analysis: variational, PDE, wavelet, and stochastic methods, SIAM, 2005.

[6] A. Hyvärinen, P. O. Hoyer and M. Inki, "Topographic independent component analysis," Neural computation, vol. 13, no. 7, pp. 1527-1558, 2001

[7] N. Hassan and D. A. Ramli, "A comparative study of blind source separation for bioacoustics sounds based on fastica, pca and nmf," Procedia Computer Science, vol. 126, pp. 363-372, 2018

[8] A. Hyvärinen and E. Oja, "Independent component analysis: algorithms and applications," Neural networks, vol. 13, no. 4-5, pp. 411-430, 2000

[9] A. Septadaya, C. Dewi and B. Rahayudi, "Implementasi Extreme Learning Machine dan Fast Independent Component Analysis untuk Klasifikasi Aritmia Berdasarkan Rekaman Elektrokardiogram," Jurnal Pengembangan Teknologi Informasi dan Ilmu Komputer e-ISSN, vol. 2548, p. 964X, 2019.

[10] "Nature image feature extraction using several sparse variants of non-negative matrix factorization algorithm," in International Symposium on Neural Networks, Springer, 2012, pp. 274-281.

[11] P. O. Hoyer, "Non-negative matrix factorization with sparseness constraints," Journal of machine learning research , vol. 5, no. 9, 2004.

[12] I. Buciu and I. Pitas, "NMF, LNMF, and DNMF modeling of neural receptive fields involved in human facial expression perception," Journal of Visual Communication and Image Representation, vol. 17, no. 5, pp. 958-969, 2006.

[13] COMON, Pierre. Independent component analysis, a new concept?. Signal processing, 1994, 36.3: 287-314.

[14] Hyvärinen, Aapo, Jarmo Hurri, and Patrik O. Hoyer. "Independent component analysis." Natural Image Statistics. Springer, London, 2009. 151-175.

[15] Della Gressinda Wahana, B. H., Aulia, S., \& Hadiyoso, S. (2020). Face Recognition System for Indoor Applications Based on Video with the LNMF and NMFsc Methods. Journal of Southwest Jiaotong University, 55(6)

[16] Zhan, C., Li, W., \& Ogunbona, P. (2012). Local representation of faces through extended NMF. Electronics letters, 48(7), 373-375.

[17] Chen, J., Feng, Y., Liu, Y., Tang, B., \& Wu, W. (2016, October) Sparse Non-negative Matrix Factorization with Generalized Kullback-Leibler Divergence. In International Conference on Intelligent Data Engineering and Automated Learning (pp. 353360). Springer, Cham.

[18] Savran, A., Sankur, B., \& Bilge, M. T. (2012). Comparative evaluation of 3D vs. 2D modality for automatic detection of facial action units. Pattern recognition, 45(2), 767-782.

[19] Ciocoiu, I. B. (2009). Localized versus Locality Preserving Representation Methods in Face Recognition Tasks. In Intelligent
Systems and Technologies (pp. 81-103). Springer, Berlin, Heidelberg.

[20] Liu, Jian, and Yuncai Liu. "A model for saliency detection using nmfsc algorithm." International Conference on Computer Analysis of Images and Patterns. Springer, Berlin, Heidelberg, 2009. 